ARAȘTIRMA MAKALESİ / RESEARCH ARTICLE

\title{
CAUSALITY LINKAGES BETWEEN INCOME INEQUALITY AND FINANCIAL GLOBALIZATION FOR G7 COUNTRIES
}

\section{G7 ÜLKELERİ İÇİN GELİR EŞİTSİZLİĞİ VE FİNANSAL KÜRESELLEŞME ARASINDAKİ NEDENSELLIK İLIŞKILLERİ}

Orkun ÇELIK ${ }^{*}$ ID

\begin{abstract}
The main aim of this study is to evaluate the causality linkages between income inequality and financial globalization for G7 countries over the period 1970-2015. The bootstrap panel Granger causality analysis by Kónya (2006) is used. The empirical results indicate that there is a causality linkage between income inequality and financial globalization in most of the G7 countries. Furthermore, it is shown that income tax has a significant role on the causality linkage. Hence, in order to reduce income inequality, policy makers should apply high taxes on top income, using fiscal policy instruments.

Keywords: Income Inequality, Financial Globalization, Tax, Income Distribution.

JEL Codes: D31, O15, O16.

Öz

Bu çalışmanın temel amacı, 1970-2015 dönemi G7 ülkeleri için gelir eşitsizliği ve finansal küreselleşme arasındaki nedensellik ilişkilerini değerlendirmektir. Kónya (2006)'a ait bootstrap panel Granger nedensellik analizinden yararlanılmaktadır. Ampirik sonuçlar, çoğu G7 ülkesinde gelir eşitsizliği ve finansal küreselleşme arasında bir nedensellik ilişkisinin var olduğunu göstermektedir. Ayrıca, gelir vergisinin bu nedensellik ilişkisi üzerinde önemli bir role sahip olduğunu gösterilmektedir. Bu nedenle, gelir eşitsizliğini azaltmak için, politikacıların maliye politikası araçlarını kullanarak en yüksek gelire sahip olanlara yüksek vergiler uygulaması gerekmektedir.
\end{abstract}

Anahtar Kelimeler: Gelir Eşitsizliği, Finansal Küreselleşme, Vergi, Gelir Dağılımı.

JEL Kodları: D31, O15, O16.

* Assist. Prof. Dr., Gümüşhane University, Department of Management and Organization, Vocational School of Social Science, Gümüşhane /TURKEY, ocelik@gumushane.edu.tr, ocelikege@gmail.com, ORCID: 0000-00028594-6852. 


\section{Introduction}

Income inequality, which influences every sphere of life, is a widespread trouble across all countries. Therefore, it is not a new phenomenon. The trends, reasons, and consequents of income inequality have been frequently discussed by many researchers.

Income inequality has increased in most OECD countries since the 1980s. In these countries, its average has enhanced by almost 10 percent to just under 32 Gini point since the mid-1980s (Keeley, 2015a: 32-33). Additionally, in G-7 and most advanced countries, the wealth and income inequality has also been increasing since the 1980s (Fine et al., 2019: 4). In theory, the Kuznets [1955] (1965) curve and the Great U-Turn by Harrison and Bluestone (1988) have dominated descriptions of historical trends in income inequality in the US and other industrial economies (Atkinson, 2003: 1-2; Alderson et al., 2005: 2). Figure 1 shows the trends of Gini coefficients in G7 countries over the period 1970-2015. As is seen in Figure 1, the Gini coefficient in market income (meaning pre-tax income) has expeditiously much increased compared to the Gini coefficient in disposable income (meaning post-tax income) since the 1980 s.

Figure 1. The Trends of the Gini Indices in G7 Countries (Average, 1970-2015)

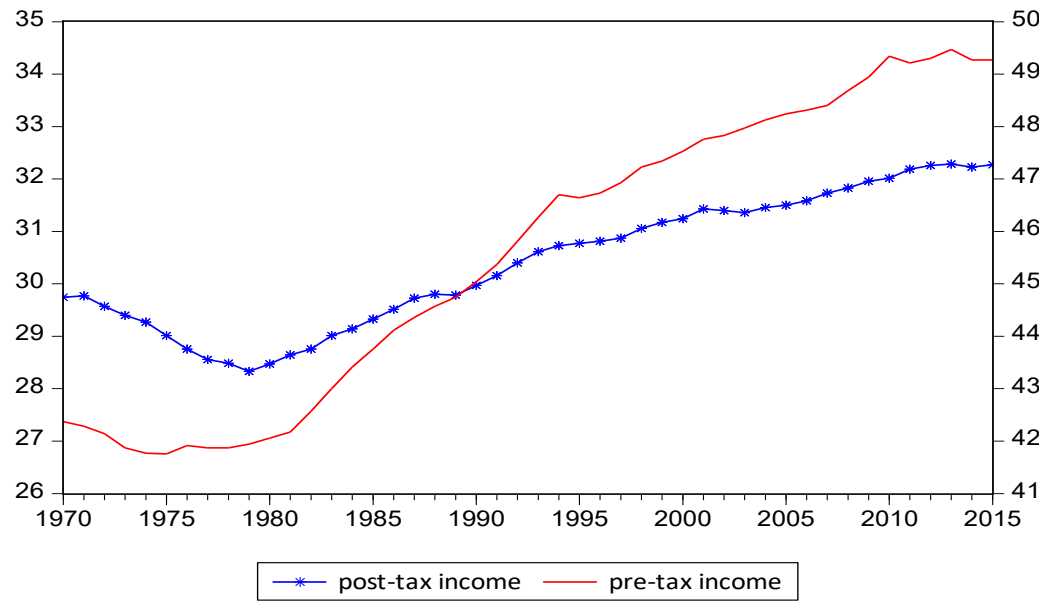

Source: Own graph. The data is obtained from SWIID database. The left and right axes show the Gini indices for post-tax income and pre-tax income, respectively.

The personal distribution of income depends on a wide variety of forces (Atkinson, 2000: 16). Also, many researchers have debated on these forces for a long time. Globalization has been much considered as the main reason of deterioration in income distribution (OECD, 2011: 24). According to the report of UNDP (2013: 72), there are two type drivers of income inequality as exogenous (e.g., trade, financial globalization, and technical change) and endogenous drivers (e.g., macroeconomic and labour market policies, wealth inequality, fiscal policies such as taxation, transfers, and government expenditure). 
Figure 2 shows the trends of trade, financial, and information globalization for G7 countries over the period 1970-2017. While trade and financial globalization have increased since the 1970s, information globalization has been stable until the early 1990s. Later, it has swiftly increased.

Figure 2. The Trends of Trade, Financial, and Information Globalization in G7 Countries (Average, 1970-

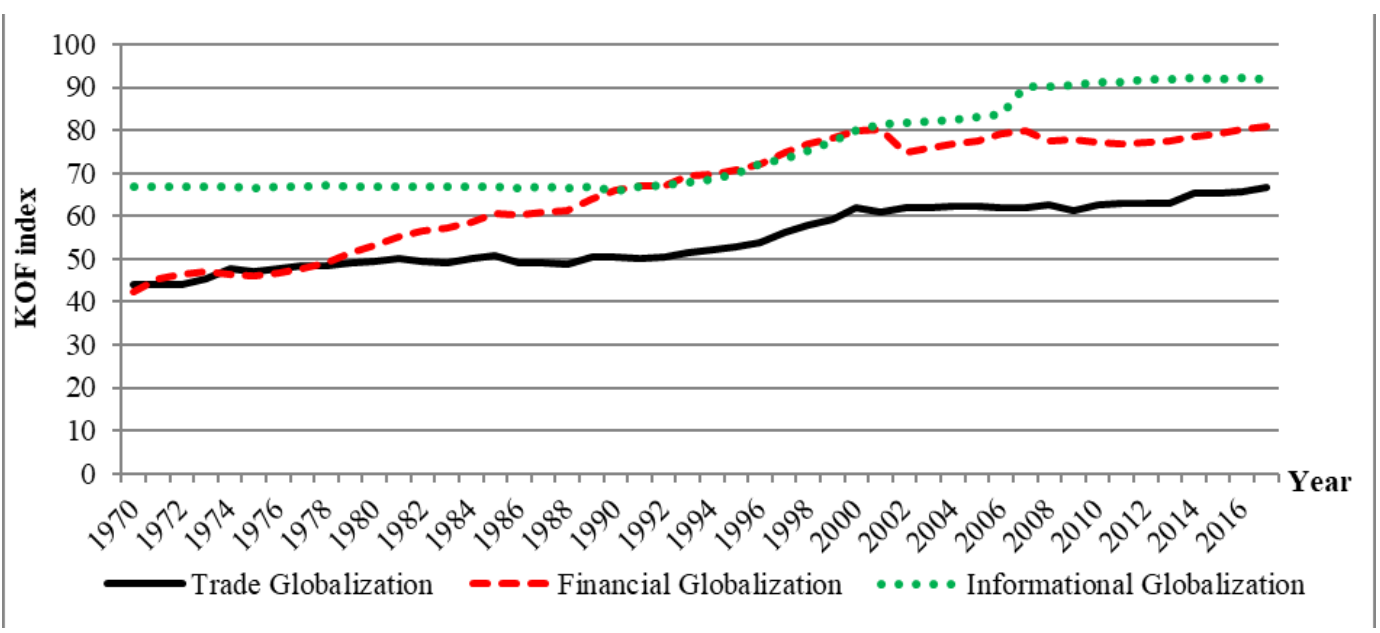

Source: Own graph. The data is obtained from KOF Swiss Economic Institute database.

As is seen Figure 2, the clearest rise in the three forms of globalization is seen in financial globalization for G7 countries since the 1970s. Therefore, especially, financial markets should be considered in determining forces of income inequality. Atkinson (2000) also suggests that it needs to be considered not just at wages but also at the capital market as there has been a shift towards capital income and a rise in the real rate of return.

Many researchers evaluate whether there is an impact of financial globalization on income inequality. Many researchers evidence that financial globalization widens income inequality (e.g., Das \& Mohapatra, 2003; Lee, 2006; Elmawazini et al., 2013; Jaumotte et al., 2013; Asteriou et al., 2014; KangKook, 2014; Daisaka et al., 2014; Bukhari \& Munir, 2016; Cabral et al., 2016; De Haan \& Sturm, 2017; Khan et al., 2019; Furceri et al., 2019; Akbakay \& Barak, 2020), while a few researchers conclude that financial globalization decreases income inequality (e.g. Agnello et al., 2012; Bumann \& Lensink, 2016; Lee et al., 2019). Additionally, some findings have differed by country groups. For instance, Çelik and Basdas (2010) find that financial globalization reduces inequality in developed and developing countries, while it enhances inequality in miracle countries. Baek and Shi (2016) show that financial globalization decreases inequality in developed countries, while it widens income inequality in developing countries.

Furthermore, as far as is known, there is no article that directly evaluates the effect of income inequality on financial globalization, except Çelik (2021). A few researchers evaluate its impact on 
financial crisis (e.g., Rajan, 2010; Bordo \& Meissner, 2012; Van Treeck, 2014; Gu \& Huang, 2014; Stockhammer, 2015; Kumhof et al., 2015; Perugini et al., 2016; Kirschenmann et al., 2016). They conclude that income inequality induces financial crisis. Çelik (2021) find the existence of bidirectional causality nexus between financial globalization and income inequality for 19 emerging market economies. Also, this study considers only emerging market economies.

Hence, the study also aims to evaluate the causality linkages between income inequality and financial globalization in G7 countries over the period 1970-2015. The study unfolds as follows. Section 1 presents information about the dataset and approach using in the analysis. Section 2 shows findings of the analysis. In conclusion and discussion section, it is given conclusions and recommends for politicians.

\section{Data and Methodology}

\subsection{Data}

In this study, the panel dataset covering the period 1970-2015 is used. The time period of the dataset cannot be extended, as income inequality can be accessed till 2015 for Japan. Table 1 indicates descriptive statistics. As is seen in Table 1, the natural logarithmic forms of all variables are used in the analysis.

Table 1. Descriptive Statistics

\begin{tabular}{cccccc}
\hline Variables & Number of Observations & Mean & Std. Dev. & Min. Value & Max. Value \\
\hline finglob & 322 & 4.149 & 0.266 & 3.437 & 4.522 \\
finglob $_{\text {de facto }}$ & 322 & 3.964 & 0.445 & 2.911 & 4.543 \\
finglob $_{\text {de jure }}$ & 322 & 4.279 & 0.197 & 3.685 & 4.535 \\
Gini $_{\text {disp }}$ & 322 & 3.409 & 0.108 & 3.203 & 3.640 \\
Gini $_{\text {mkt }}$ & 322 & 3.815 & 0.099 & 3.569 & 3.989 \\
\hline
\end{tabular}

Note: Std. Dev.: Standard deviation, Min. Value: Minimum value, Max. Value: Maximum value.

Researchers have great difficulty in accessing the data regarding income inequality. They have generally obtained from the databases such as Standardized World Income Inequality (SWIID hereafter, see Bergh \& Nilsson, 2010; Kunieda et al., 2014; De Haan \& Sturm, 2017; Dorn et al., 2018; Furceri \& Loungani, 2018; Furceri et al., 2019; Akbakay \& Barak, 2020), World Income Inequality Database (WIID hereafter, see Bukhari \& Munir, 2016), World Bank (see Elmawazini et al., 2013; Jaumotte et al., 2013; Khan et al., 2019), EUROSTAT-SILC (see Asterio et al., 2014), and OECD (see Baek \& Shi, 2016). In this study, SWIID 8.2 version is preferred compared to WIID database (see De Haan and Sturm (2017) for advantages of using SWIID database). 
The SWIID database has been provided estimates of income inequality for as many countries and years as possible. In this database, there are two different Gini values regarding income inequality. There are disposable and market Gini values. The disposable and the market Gini express estimate of Gini index of inequality in equalised household disposable (post-tax, post-transfer) income, and in equalised household market (pre-tax, pre-transfer) income, respectively. The Luxembourg Income Study data is benefited as the standard in these estimations (Solt, 2019). These values are defined as Gini $_{\text {disp }}$ (Gini value of disposable (net) income) and Gini ${ }_{m k t}$ (Gini value of market (gross) income).

The data regarding financial globalization is obtained from KOF database (see Gygli et al., 2019). This database is generated by Swiss Economic Institute and measures the economic, social and political aspects of globalization. It is used in some studies that investigate the linkage between inequality and financial globalization (e.g. Dorn et al., 2018; Akbakay \& Barak, 2020). Three variables (de facto, de jure, and overall) are considered for financial globalization. Financial globalization (de facto) and financial globalization (de jure) are denoted as finglob de facto as finglob $_{\text {de jure }}$, respectively. The financial globalization (de facto) covers foreign direct investment, portfolio investment, international debt, income payments and reserves, while financial globalization (de jure) consists of investment restrictions, capital account openness, and international investment agreements. The last one is overall financial globalization index (KOF).

Furthermore, government is playing a major role in reducing of income inequality, through the taxes it collects and the benefits it pays out (Keeley, 2015b: 42). Hence, the role of tax on the linkage between income inequality and financial globalization is investigated for G7 countries, with considering two different Gini variables (for pre-tax and post-tax income). Appendix 1 and Appendix 2 demonstrate the scatter plots of income inequality by pre-tax and post-tax income and financial globalization. They show that the slopes of regression lines generally decrease after tax.

\subsection{Methodology}

The bootstrap panel Granger causality analysis ${ }^{1}$ by Kónya (2006) is employed, as it considers cross-section dependence and cross-country heterogeneity, unlike the bootstrap panel causality test Dumitrescu and Hurlin (2012) (see Wolde-Rufael (2014) for the detailed information). These factors are very important in using the analysis. Table 2 demonstrates test statistics regarding the cross-section dependence and cross-country heterogeneity. For these test statistics, the panel model is considered as;

$\operatorname{Gini}_{i t}=\vartheta_{i}+\gamma_{i}$ finglob $_{i t}+\varepsilon_{i t}$ for $i=1,2, \ldots, N ; t=1,2, \ldots, T$

where Gini shows the coefficient of income inequality, finglob is financial globalization index by $\mathrm{KOF}$, and $\varepsilon$ is error term. $i$ and $t$ denote the number of cross-sections and time periods, respectively. $\vartheta_{i}$ indicates the individual intercepts, and $\gamma_{i}$ denotes the slope coefficients, as well.

1 It is used in articles regarding the globalization and income inequality linkage (e.g. Balan et al., 2015; Destek, 2018). 
Table 2. The Cross-section Dependence and Cross-country Heterogeneity Tests

\begin{tabular}{|c|c|c|c|c|}
\hline \multirow{6}{*}{ 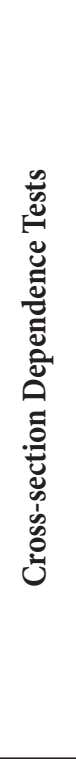 } & Author(s) & Tests & Test Statistics & Applicable \\
\hline & $\begin{array}{l}\text { Breusch } \\
\text { and Pagan } \\
(1980)\end{array}$ & LM test & $L M=T \sum_{i=1} \sum_{j=i+1} \hat{\rho}_{i j}^{2}$ & $N$ is fixed, $T \rightarrow \infty$ \\
\hline & $\begin{array}{l}\text { Pesaran } \\
(2004)\end{array}$ & LM test & $C D_{l m}=\sqrt{\frac{1}{N(N-1)}} \sum_{i=1}^{N-1} \sum_{j=i+1}^{N}\left(T \hat{\rho}_{i j}^{2}-1\right)$ & $\begin{array}{l}T \rightarrow \infty, N \rightarrow \infty \text {, but } \\
\text { it is not appropriate for } \\
\qquad N>T\end{array}$ \\
\hline & $\begin{array}{c}\text { Pesaran } \\
(2004)\end{array}$ & CD test by & $C D=\sqrt{\frac{2 T}{N(N-1)}}\left(\sum_{i=1}^{N-1} \sum_{j=i+1}^{N} \hat{\rho}_{i j}\right)$ & $T \rightarrow \infty, N \rightarrow \infty$ \\
\hline & & The bi- & $L M_{\text {adj }}$ & $\begin{array}{l}\text { It is appropriate even } \\
\text { when the CD test is in- }\end{array}$ \\
\hline & $\begin{array}{l}\text { Pesaran et } \\
\text { al. }(2008)\end{array}$ & $\begin{array}{l}\text { as-ad- } \\
\text { justed LM } \\
\text { test }\end{array}$ & $=\sqrt{\frac{2}{N(N-1)} \sum_{i=1}^{N-1} \sum_{j=i+1}^{N} \frac{(T-k) \hat{\rho}_{i j}^{2}-\mu_{T i j}}{v_{T i j}}}$ & $\begin{array}{l}\text { consistent. Moreover, } \\
\text { it is suggested under } \\
\text { local error cross-sec- } \\
\text { tion dependence of any } \\
\text { fixed order } p \text {. }\end{array}$ \\
\hline 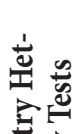 & $\begin{array}{l}\text { Pesaranand } \\
\text { Yamagata } \\
(2008)\end{array}$ & Delta Test & $\tilde{\Delta}=\sqrt{N}\left(\frac{N^{-1} \tilde{S}-k}{\sqrt{2 k}}\right)$ & $(N, T) \rightarrow \infty$ \\
\hline 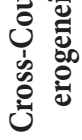 & $\begin{array}{l}\text { Pesaranand } \\
\text { Yamagata } \\
(2008)\end{array}$ & $\begin{array}{l}\text { The bias- } \\
\text { adjusted } \\
\text { Delta Test }\end{array}$ & $\widetilde{\Delta}_{a d j}=\sqrt{N}\left(\frac{N^{-1} \tilde{S}-E\left(\tilde{z}_{i t}\right)}{\sqrt{\operatorname{var}\left(\tilde{z}_{i t}\right)}}\right)$ & $\begin{array}{l}\text { For the small sam- } \\
\text { ple properties of the } \\
\text { test } \tilde{\Delta} \text {. }\end{array}$ \\
\hline
\end{tabular}

Source: Own table. Note: $\hat{\rho}_{i j}$ denotes the sample estimation of the correlation of the residuals that are obtained from the OLS estimation. The delta test bases on the Swamy (1970)'s slope homogeneity test; $S=\sum_{i=1}^{N}\left(\hat{\gamma}_{i}-\hat{\gamma}_{w f e}\right)^{\prime} \frac{x_{i}^{\prime} M_{\tau} x_{i}}{\hat{\sigma}_{i}^{2}}\left(\hat{\gamma}_{i}-\hat{\gamma}_{w f e}\right) . \hat{\gamma}_{i}$ is the pooled OLS estimator and $\hat{\gamma}_{w f e}$ is the weighted fixed effect pooled OLS estimator. $M_{\tau}$ denotes an identify matrix of order $T$, where $\tau_{T}$ is a $T \times 1$ vector of ones. $\hat{\sigma}_{i}^{2}$ presents the estimator of error variance (Chu, 2012; Chang et al., 2013). See Breusch and Pagan (1980), Pesaran (2004), Pesaran et al. (2008), Pesaran and Yamagata (2008) for the detailed information. The null hypothesis is no-cross-section dependence in the cross-section dependence tests, whereas it is no-slope heterogeneity (homogeneity is valid) for the cross-country heterogeneity tests.

With considering cross section dependence and cross-country heterogeneity, the bootstrap panel Granger causality analysis by Kónya (2006) is applied. It bases on seemingly unrelated regression (SUR hereafter) estimation and the critical values of the Wald test. The following the panel models are estimated:

$$
\begin{aligned}
& \operatorname{Gini}_{1 t}=\vartheta_{11}+\sum_{l=1}^{m 1} \gamma_{11 l} \text { Gini }_{1 t-l}+\sum_{l=1}^{m 1} \beta_{11 l} \text { finglob }_{1 t-l}+\varepsilon_{11 t} \\
& :: \\
& \text { Gini }_{N t}=\vartheta_{1 N}+\sum_{l=1}^{m 1} \gamma_{1 N l} \text { Gini }_{N t-l}+\sum_{l=1}^{m 1} \beta_{1 N l} \text { finglob }_{N t-l}+\varepsilon_{1 N t}
\end{aligned}
$$

and 


$$
\begin{aligned}
& \text { finglob }_{1 t}=\vartheta_{21}+\sum_{l=1}^{m 2} \gamma_{21 l} \text { finglob }_{1 t-l}+\sum_{l=1}^{m 2} \beta_{21 l} \text { Gini }_{1 t-l}+\varepsilon_{21 t} \\
& \vdots:
\end{aligned}
$$

$$
\text { finglob }_{N t}=\vartheta_{2 N}+\sum_{l=1}^{m 2} \gamma_{2 N l} \text { finglob }_{N t-l}+\sum_{l=1}^{m 2} \beta_{2 N l} \text { Gini }_{N t-l}+\varepsilon_{2 N t}
$$

where $l$ is the lag length, Gini is income inequality, and finglob is financial globalization. $N$ and $T$ demonstrate the number of countries and time period, respectively. $i=1, \ldots, N$ and $t=1, \ldots, T$. The baseline model consists of finglob, Gini $i_{\text {disp }}$, and Gini $_{m k t}$ variables. To test the robustness of the baseline model, two different variables ( finglob $_{\text {de facto }}$ and finglob de jure $_{\text {) }}$ are considered for financial globalization. Furthermore, the Wald statistics are compared with the critical values at 1,5 , and 10 percent significance level for determining of the direction of causality.

\section{Empirical Findings}

In order to evaluate the linkages between income inequality and financial globalization for G7 countries, the bootstrap panel Granger causality analysis by Kónya (2006) is employed. Table 3 displays the results of the baseline model. Moreover, Table 4 and Table 5 indicate the results of ro-

\begin{tabular}{|c|c|c|c|c|c|c|c|c|c|c|}
\hline \multirow[b]{3}{*}{ Country } & \multicolumn{5}{|c|}{$\underline{\text { finglob } \rightarrow \text { Gini }_{\text {disp }}}$} & \multicolumn{5}{|c|}{$\underline{\text { finglob } \rightarrow \text { Gini }_{m k t}}$} \\
\hline & \multirow[b]{2}{*}{ WS } & \multirow[b]{2}{*}{$\mathrm{Bp}$} & \multicolumn{3}{|c|}{ Critical Values } & \multirow[b]{2}{*}{ WS } & \multirow[b]{2}{*}{ Bp } & \multicolumn{3}{|c|}{ Critical Values } \\
\hline & & & $\% 1$ & $\% 5$ & $\% 10$ & & & $\% 1$ & $\% 5$ & $\% 10$ \\
\hline Canada & $24.14^{* * *}$ & 0.00 & 15.2 & 13.25 & 12.25 & 18.02 & 0.46 & 31.49 & 26.49 & 24.28 \\
\hline France & 2.15 & 0.49 & 5.08 & 4.08 & 3.6 & 0.32 & 0.94 & 3.09 & 2.39 & 2.06 \\
\hline Germany & $32.55^{\star * \star}$ & 0.00 & 13.29 & 11.19 & 10.28 & $13.61^{* *}$ & 0.02 & 14.06 & 11.63 & 10.46 \\
\hline Italy & $17.82^{* * *}$ & 0.00 & 5.49 & 4.24 & 3.65 & $64.55^{* * *}$ & 0.00 & 16.63 & 13.75 & 12.32 \\
\hline Japan & $46.13^{\star * *}$ & 0.00 & 19.05 & 15.23 & 13.41 & $27.91^{* * *}$ & 0.00 & 20.17 & 15.79 & 13.75 \\
\hline UK & $14.77^{* *}$ & 0.02 & 15.89 & 13.28 & 12.01 & $19.24^{* * *}$ & 0.00 & 11.65 & 8.97 & 7.83 \\
\hline US & 0.33 & 0.99 & 17.22 & 13.28 & 11.59 & 0.8 & 0.96 & 15.27 & 11.53 & 9.81 \\
\hline \multicolumn{11}{|l|}{ CD tests } \\
\hline$L M$ & $472.42^{\star * *}$ & 0.00 & & & & $589.85^{\star * *}$ & 0.00 & & & \\
\hline$C D_{l m}$ & $69.66^{* * *}$ & 0.00 & & & & $87.78^{* * *}$ & 0.00 & & & \\
\hline$C D$ & $21.11^{* * *}$ & 0.00 & & & & $23.94^{* * *}$ & 0.00 & & & \\
\hline$L M_{a d j}$ & $6.38^{* * *}$ & 0.00 & & & & $10.75^{\star * *}$ & 0.00 & & & \\
\hline \multicolumn{11}{|l|}{ Slope H.T. } \\
\hline$\tilde{\Delta}$ & $37.54^{* * *}$ & 0.00 & & & & $43.82^{* * *}$ & 0.00 & & & \\
\hline$\tilde{\Delta}_{a d j}$ & $38.79^{* * *}$ & 0.00 & & & & $45.29^{* * *}$ & 0.00 & & & \\
\hline
\end{tabular}
bustness checks.

Table 3. The Income Inequality and Financial Globalization Linkages for G7 Countries 


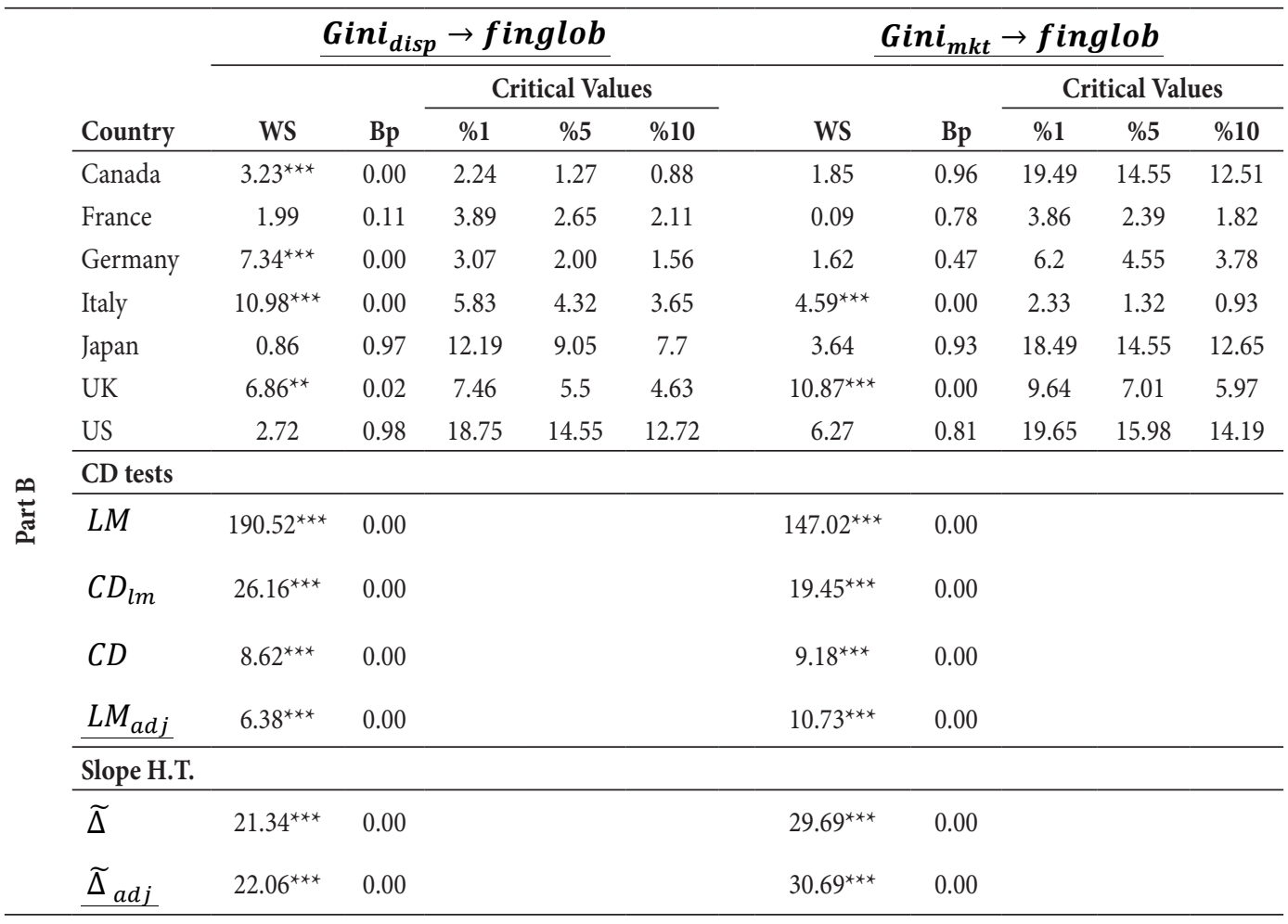

Note: WS: Wald Statistic, Bp: Bootstrap p-value, H.T: Heterogeneity Test. The number of the bootstrap replications is 10000. The maximum number of the lag length is 2 and the lag lengths are determined by AIC. ${ }^{* *} \mathrm{p}<0.01,{ }^{* *} \mathrm{p}<0.05,{ }^{*} \mathrm{p}<0.1$.

Before estimation, the cross-section dependence and cross-country heterogeneity are tested for each model. Hence, the cross-section dependence test statistics $\left(L M, C D_{l m}, C D\right.$, and $L M_{a d j}$ and cross-country heterogeneity test statistics $\left(\widetilde{\Delta}\right.$ and $\left.\widetilde{\Delta}_{a d j}\right)$ are used. All results evidence that there is the cross-section dependence among countries and homogeneity is not valid. Stated in other words, the analysis can be applied.

Table 3 show the income inequality and financial globalization linkages for G7 countries. Table 3 consists of two parts (Part A and Part B). Part A demonstrates the results of the Granger causality running from financial globalization to income inequality. The Granger causality running from financial globalization to income inequality by both disposable and market income is seen in Germany, Italy, Japan, and the UK. The Granger causality for Canada is seen in only the disposable income. Financial globalization has induced income inequality in these countries. These results are consistent with Das and Mohapatra (2003), Lee (2006), Elmawazini et al. (2013), Jaumotte et al. (2013), Asteriou et al. (2014), Kang-Kook (2014), Daisaka et al. (2014), Bukhari and Munir (2016), Cabral et al. (2016), De Haan and Sturm (2017), Khan et al. (2019), Furceri et al. (2019), Akbakay and Barak (2020), Çelik (2021), unlike Agnello et al. (2012), Bumann and Lensink (2016), Lee et al. (2019). Part B shows the results of the Granger causality running from income inequality to financial globalization. The results demonstrate that there is Granger causality linkage in Canada, Germany, 
Italy, and the UK for disposable income, while the causality linkage is seen in Italy and the UK for market income. They indicate that income inequality has induced financial globalization. In general, the empirical findings present that there is the bidirectional Granger causality linkage between these variables in Canada, Germany, Italy, and the UK. This result may be a new evidence for the literature.

To test the robustness of the findings, two different financial globalization indices (de facto and de jure) are used (see Section 1.1 for the detailed information about these indices). Table 4 and Table 5 present the robustness check results. Table 4 presents the income inequality and financial globalization (de facto) linkages for G7 countries. In Part A, financial globalization (de facto) differently influences income inequality according to income types, except France. The Granger causality running from financial globalization (de facto) to income inequality is observed in Canada, Germany and Italy for disposable income, while it is seen in Japan, the UK, and the US for market income. In Part B, there is the Granger causality linkage running from income inequality to financial globalization (de facto) in Canada, Germany, and Italy for disposable income, while it is seen in France, Germany, and Italy for market income. The bidirectional Granger causality linkage is observed in Canada, Germany, and Italy.

Table 5 indicates the income inequality and financial globalization (de jure) linkages for G7 countries. The results relatively differ from the results in Table 4. As is seen in Part A of Table 5, the Granger causality linkage running from financial globalization to income inequality is observed in most of the countries for disposable income, except Germany and the US, while it is seen in Germany, Italy, Japan, and the UK for market income. Part B shows the results of the Granger causality linkage running from income inequality to financial globalization. Accordingly, the causality linkage is seen only in Italy for two income types.

In sum, the results in Table 4 and Table 5 support the findings of Table 3 . There is a causality linkage between income inequality and financial globalization for G7 countries. Especially, the linkage is clearer in Italy and Germany within G7 countries. For Italy, Quintano et al. (2009) analyse income inequality for the period 1991-2004. They detect a peak in the income inequality in 1998 and suggest that the trend is due to the income from financial assets.

After tax, the impact of financial globalization on income inequality is clear in Germany. Hence, tax system can be a significant driver of income inequality in Germany. This remark is supported by Biewen and Juhasz (2012) and Schmid and Stein (2013). Biewen and Juhasz (2012) investigate determinants of rising income inequality for Germany over the period from 1999/2000 to 2005/2006. They indicate that the determinants of rising income inequality are the increasing income inequality in labor income, changes in employment outcomes and in the tax system. Additionally, Schmid and Stein (2013) investigate determinants of income inequality for Germany over the period 1991-2010. They suggest that the determinants are cyclical and structural changes in the labor market, the increasing relevance of capital income, and the decreasing effectiveness of the public mechanisms of income redistribution. Furthermore, they show that decline of redistributive effectiveness of taxes and public transfers induce rising of inequality in net income. 
Table 4. The Income Inequality and Financial Globalization (de facto) Linkages for G7 Countries (Robustness Checks)

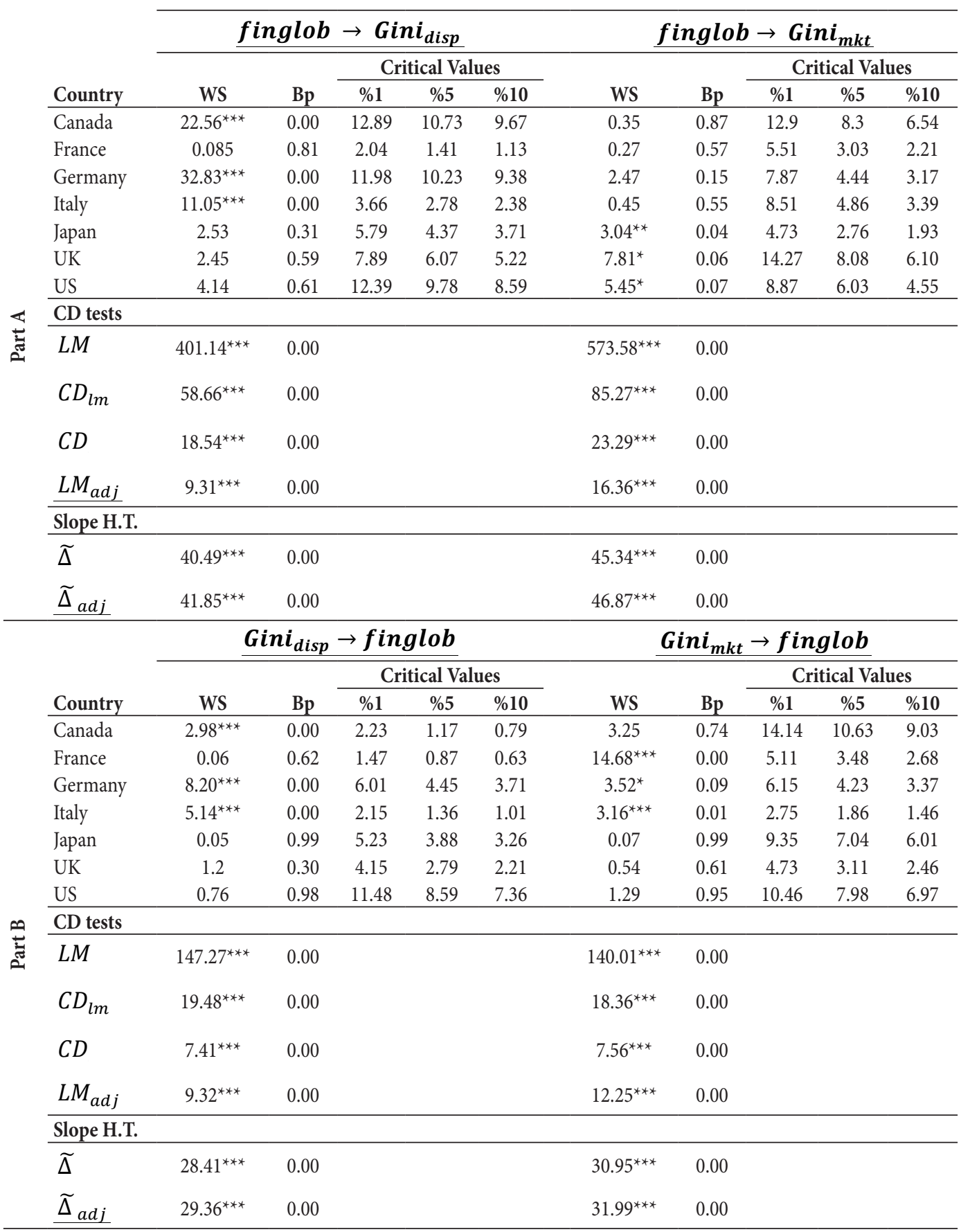

Note: WS: Wald Statistic, Bp: Bootstrap p-value, H.T: Heterogeneity Test. The number of the bootstrap replications is 10000. The maximum number of the lag length is 2 and the lag lengths are determined by AIC. ${ }^{* *} \mathrm{p}<0.01,{ }^{* *} \mathrm{p}<0.05,{ }^{*} \mathrm{p}<0.1$. 
Table 5. The Income Inequality and Financial Globalization (de jure) Linkages for G7 Countries (Robustness Checks)

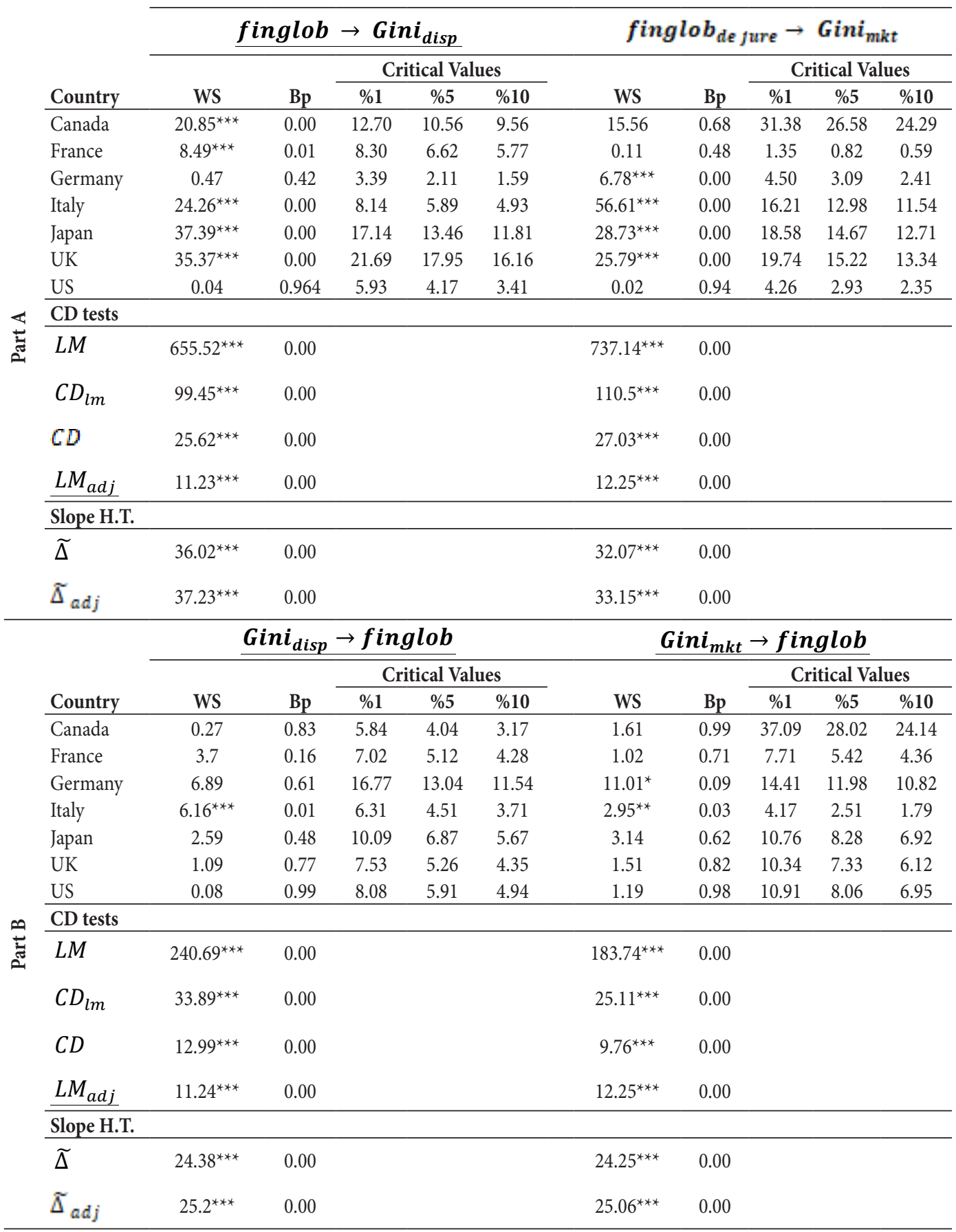

Note: WS: Wald Statistic, Bp: Bootstrap p-value, H.T: Heterogeneity Test. The number of the bootstrap replications is 10000. The maximum number of the lag length is 2 and the lag lengths are determined by AIC. ${ }^{* *} \mathrm{p}<0.01,{ }^{* *} \mathrm{p}<0.05,{ }^{*} \mathrm{p}<0.1$. 


\section{Conclusion and Discussion}

The main aim of this study is to evaluate the causality linkages between income inequality and financial globalization for G7 countries over the period 1970-2015. For the objective, the bootstrap panel Granger causality analysis by Kónya (2006) is used, as it considers the cross-section dependence and cross-country heterogeneity. To investigate the role of tax on the causality linkage, two Gini coefficient indices are also considered (for pre-tax income and post-tax income).

The results indicate that there is a causality nexus between income inequality and financial globalization for most G7 countries. In general, the Granger causality linkage running from financial globalization to income inequality is seen in Canada, Germany, Japan, Italy, and the UK. The results are line with the studies of many researchers (e.g., Das \& Mohapatra, 2003; Lee, 2006; Elmawazini et al., 2013; Jaumotte et al., 2013; Asteriou et al., 2014; Kang-Kook, 2014; Daisaka et al., 2014; Bukhari \& Munir, 2016; Cabral et al., 2016; De Haan \& Sturm, 2017; Khan et al., 2019; Furceri et al., 2019; Akbakay \& Barak, 2020; Çelik, 2021), unlike Agnello et al. (2012), Bumann and Lensink (2016), Lee et al. (2019). Moreover, the Granger causality linkage running from income inequality to financial globalization is clearly observed in Italy and the UK.

Additionally, the tax has a significant role on the linkage. All these results are very significant for policy makers. In order to reduce income inequality, they may apply a higher tax rate on the top income (\%1). Therefore, it can provide the fairness in tax system. Furthermore, they should more control over financial assets/incomes which have expeditiously increased in recent years.

\section{References}

Agnello, L., Mallick, S.K., \& Sousa, R.M. (2012). Financial reforms and income inequality. Economics Letters, 116(3), 583-587. DOI: 10.1016/j.econlet.2012.06.005

Akbakay, Z., \& Barak, D. (2020). Yükselen piyasalarda ekonomik küreselleşme ve gelir eşitsizliği ilişkisi. Uluslararası Yönetim İktisat ve İşletme Dergisi, 16(1), 17-34. DOI: 10.17130/ijmeb.700812

Alderson, A.S., Beckfield, J., \& Nielsen, F. (2005). Exactly how has income inequality changed? Patterns of distributional change in core societies. Luxembourg Income Study Working Paper Series, No. 422.

Asteriou, D., Dimelis, S., \& Moudatsou, A. (2014). Globalization and income inequality: A panel data econometric approach for the EU27 countries. Economic Modelling, 36, 592-599. DOI: 10.1016/j.econ$\bmod .2013 .09 .051$

Atkinson, A.B. (2000). The changing distribution of income: Evidence and explanations. German Economic Review, 1(1), 3-18. DOI: 10.1111/1468-0475.00002

Atkinson, A.B. (2003). Income inequality in OECD countries: Data and explanations. Center for Economic Studies and Ifo Institute (CESifo) Working Paper, No. 881.

Baek, I., \& Shi, Q. (2016). Impact of economic globalization on income inequality: Developed economies vs emerging economies. Global Economy Journal, 16(1), 49-61. DOI: 10.1515/gej-2015-0047

Balan, F., Torun, M., \& Kilic, C. (2015). Globalization and income inequality in G7: A bootstrap panel Granger causality analysis. International Journal of Economics and Finance, 7(10), 192-203.

Bergh, A., \& Nilsson, T. (2010). Do liberalization and globalization increase income inequality? European Journal of political economy, 26(4), 488-505. DOI: 10.1016/j.ejpoleco.2010.03.002 
Biewen, M., \& Juhasz, A. (2012). Understanding rising income inequality in Germany, 1999/2000-2005/2006. Review of Income and Wealth, 58(4), 622-647. DOI: 10.1111/j.1475-4991.2012.00514.x

Bordo, M.D., \& Meissner, C.M. (2012). Does inequality lead to a financial crisis? Journal of International Money and Finance, 31(8), 2147-2161. DOI: 10.1016/j.jimonfin.2012.05.006

Breusch, T.S., \& Pagan, A.R. (1980). The Lagrange multiplier test and its applications to model specification in econometrics. The Review of Economic Studies, 47(1), 239-253. DOI: 10.2307/2297111

Bukhari, M., \& Munir, K. (2016). Impact of globalization on income inequality in selected Asian countries. Munich Personal RePEc Archive. MPRA Paper No. 74248.

Bumann, S., \& Lensink, R. (2016). Capital account liberalization and income inequality. Journal of International Money and Finance, 61, 143-162. DOI: 10.1016/j.jimonfin.2015.10.004

CabraL, R., García-Díaz, R., \& Mollick, A.V. (2016). Does globalization affect top income inequality? Journal of Policy Modeling, 38(5), 916-940. DOI: 10.1016/j.jpolmod.2016.05.001

ÇELIK, O. (2021). The Nexus Between Financial Globalization and Income Inequality: The Case of Emerging Market Economies. Pamukkale Üniversitesi Sosyal Bilimler Enstitüsü Dergisi, 44, 339-355. DOI: 10.30794/pausbed.789689

Çelik, S., \& Basdas, U. (2010). How does globalization affect income inequality? A panel data analysis. International Advances in Economic Research, 16(4), 358-370. DOI: 10.1007/s11294.010.9281-0

Chang, T., Cheng, S.C., Pan, G., \& Wu, T.P. (2013). Does globalization affect the insurance markets? Bootstrap panel Granger causality test. Economic Modelling, 33, 254-260. DOI: 10.1016/j.econmod.2013.04.008

Chu, H.P. (2012). Oil consumption and output: What causes what? Bootstrap panel causality for 49 countries. Energy Policy, 51, 907-915. DOI: 0.1016/j.enpol.2012.09.050

Daisaka, H., Furusawa, T., \& Yanagawa, N. (2014). Globalization, financial development and income inequality. Pacific Economic Review, 19(5), 612-633. DOI: 10.1111/1468-0106.12086

Das, M., \& Mohapatra, S. (2003). Income inequality: the aftermath of stock market liberalization in emerging markets. Journal of Empirical Finance, 10(1-2), 217-248. DOI: 10.1016/S0927-5398(02)00025-7

De Haan, J., \& Sturm, J.E. (2017). Finance and income inequality: A review and new evidence. European Journal of Political Economy, 50, 171-195. DOI: 10.1016/j.ejpoleco.2017.04.007

Destek, M.A. (2018). Dimensions of globalization and income inequality in transition economies: taking into account cross-sectional dependence. Eastern Journal of European Studies, 9(2), 5-25.

Dorn, F., Fuest, C., \& Potrafke, N. (2018). Globalization and income inequality revisited. CESifo Working Paper No. 6859.

Dumitrescu, E-I \& Hurlin, C. (2012). Testing for Granger non-causality in heterogeneous panels. Economic Modelling, 29(4), 1450-1460. DOI: 10.1016/j.econmod.2012.02.014

Elmawazini, K., Sharif, A., Manga, P., \& Drucker, P. (2013). Trade globalization, financial globalization and inequality within south-east Europe and cis countries. The Journal of Developing Areas, 303-317.

Fine, D., Manyika, J., Sjatil, P.E., Tacke, T., Tadjeddine, K., \& Desmond, M. (2019). Inequality: A persisting challenge and its implications. McKinsey Global Institute, Discussion Paper. June 2019.

Furceri, D., \& Loungani, P. (2018). The distributional effects of capital account liberalization. Journal of Development Economics, 130, 127-144. DOI: 10.1016/j.jdeveco.2017.09.007

Furceri, D., Loungani, P., \& Ostry, J.D. (2019). The aggregate and distributional effects of financial globalization: Evidence from macro and sectoral data. Journal of Money, Credit and Banking, 51, 163-198. DOI: 10.1111/jmcb. 12668

Gu, X., \& Huang, B. (2014). Does inequality lead to a financial crisis? Revisited. Review of Development Economics, 18(3), 502-516. DOI: 10.1111/rode.12099 
Gygli, S., Haelg, F., Potrafke, N., \& Sturm, J.E. (2019). The KOF globalisation index-revisited. The Review of International Organizations, 14(3), 543-574. DOI: 10.1007/s11558.019.09344-2

Harrison, B., \& bluestone, B. (1988). The great u-turn: Corporate restructuring and the polarizing of America. New York: Basic Books.

Jaumotte, F., Lall, S., \& Papageorgiou, C. (2013). Rising income inequality: technology, or trade and financial globalization? IMF Economic Review, 61(2), 271-309. DOI: 10.1057/imfer.2013.7

Kang-Kook, L. (2014). Globalization, income inequality and poverty: Theory and empirics. Social System Studies, 28, 109-134.

Keeley, B. (2015a). What's happening to income inequality? In: Income Inequality: The Gap between Rich and Poor, Paris: OECD Publishing. DOI: DOI: 10.1787/978.926.4246010-4-en

Keeley, B. (2015b). Why is income inequality rising? In: Income Inequality: The Gap between Rich and Poor, Paris: OECD Publishing. DOI: 10.1787/978.926.4246010-5-en

Khan, H., Shehzad, C.T., \& Ahmad, F. (2019). Temporal effects of financial globalization on income inequality. DOI: $10.2139 /$ ssrn.3509061

Kirschenmann, K., Malinen, T., \& Nyberg, H. (2016). The risk of financial crises: Is there a role for income inequality? Journal of International Money and Finance, 68, 161-180. DOI: 10.1016/j.jimonfin.2016.07.010

Kónya, L. (2006). Exports and growth: Granger causality analysis on OECD countries with a panel data approach. Economic Modelling, 23(6), 978-992. DOI: 10.1016/j.econmod.2006.04.008

Kumhof, M., Rancière, R., \& Winant, P. (2015). Inequality, leverage, and crises. American Economic Review, 105(3), 1217-1245. DOI: 10.1257/aer.20110683

Kunieda, T., Okada, K., \& Shibata, A. (2014). Finance and inequality: How does globalization change their relationship? Macroeconomic Dynamics, 18(5), 1091-1128. DOI: 10.1017/S136.510.0512000843

Kuznets, S. [1955] 1965. Economic growth and income inequality. In: Economic growth and structure. New York: Norton.

Lee, J.E. (2006). Inequality and globalization in Europe. Journal of Policy Modeling, 28(7), 791-796. DOI: 10.1016/j.jpolmod.2006.04.013

Lee, W.C., Cheong, T.S., Wu, Y., \& Wu, J. (2019). The impacts of financial development, urbanization, and globalization on income inequality: A regression-based decomposition approach. Asian Economic Papers, 18(2), 126-141. DOI: 10.1162/asep_a_00703

OECD (2011). An overview of growing income inequalities in OECD countries: Main findings. In: Divided we stand: Why inequality keeps rising, Paris: OECD Publishing, DOI: 10.1787/978.926.4119536-en

Perugini, C., Hölscher, J., \& Collie, S. (2016). Inequality, credit and financial crises. Cambridge Journal of Economics, 40(1), 227-257. DOI: 10.1093/cje/beu075

Pesaran, M.H. (2004). General diagnostic tests for cross section dependence in panels. IZA Discussion Paper No. 1240.

Pesaran, M.H., \& Yamagata, T. (2008). Testing slope homogeneity in large panels. Journal of Econometrics, 142(1), 50-93. DOI: 10.1016/j.jeconom.2007.05.010

Pesaran, M.H., Ullah, A., \& Yamagata, T. (2008). A bias-adjusted LM test of error cross-section independence. The Econometrics Journal, 11(1), 105-127. DOI: 10.1111/j.1368-423X.2007.00227.x

Quintano, C., Castellano, R., \& Regoli, A. (2009). Evolution and decomposition of income inequality in Italy, 1991-2004. Statistical Methods and Applications, 18(3), 419-443. DOI: 10.1007/s10260.008.0101-0

Rajan, R.G. (2010). Fault lines: How hidden fractures still threaten the world economy. New Jersey: Princeton University Press. 
Schmid, K., \& Stein, U. (2013). Explaining rising income inequality in Germany, 1991-2010. SOEP Paper No. 592.

Solt, F. (2019). Measuring income inequality across countries and over time: The standardized world income inequality database. SWIID Version 8.2, November 2019.

Stockhammer, E. (2015). Rising inequality as a cause of the present crisis. Cambridge Journal of Economics, 39(3), 935-958. DOI: 10.1093/cje/bet052

Swamy, P.A. (1970). Efficient inference in a random coefficient regression model. Econometrica: Journal of the Econometric Society, 311-323. DOI: 10.2307/1913012

UNDP (2013). Humanity divided: Confronting inequality in developing countries. New York: UNDP.

Van Treeck, T. (2014). Did inequality cause the US financial crisis? Journal of Economic Surveys, 28(3), 421-448. DOI: $10.1111 /$ joes.12028

Wolde-Rufael, Y. (2014). Electricity consumption and economic growth in transition countries: A revisit using bootstrap panel Granger causality analysis. Energy Economics, 44, 325-330. DOI: 10.1016/j. eneco.2014.04.019

\section{Internet Resources}

KOF, https://kof.ethz.ch/en/forecasts-and-indicators/indicators/kof-globalisation-index.html (Accessed 15 April 2020).

SWIID, https://dataverse.harvard.edu/dataset.xhtml?persistentId=doi:10.7910/DVN/LM4OWF (Accessed 15 April 2020). 
Appendix 1: The Role of Tax on the Effect of Financial Globalization on Income Inequality for G7 Countries (1970-2015)
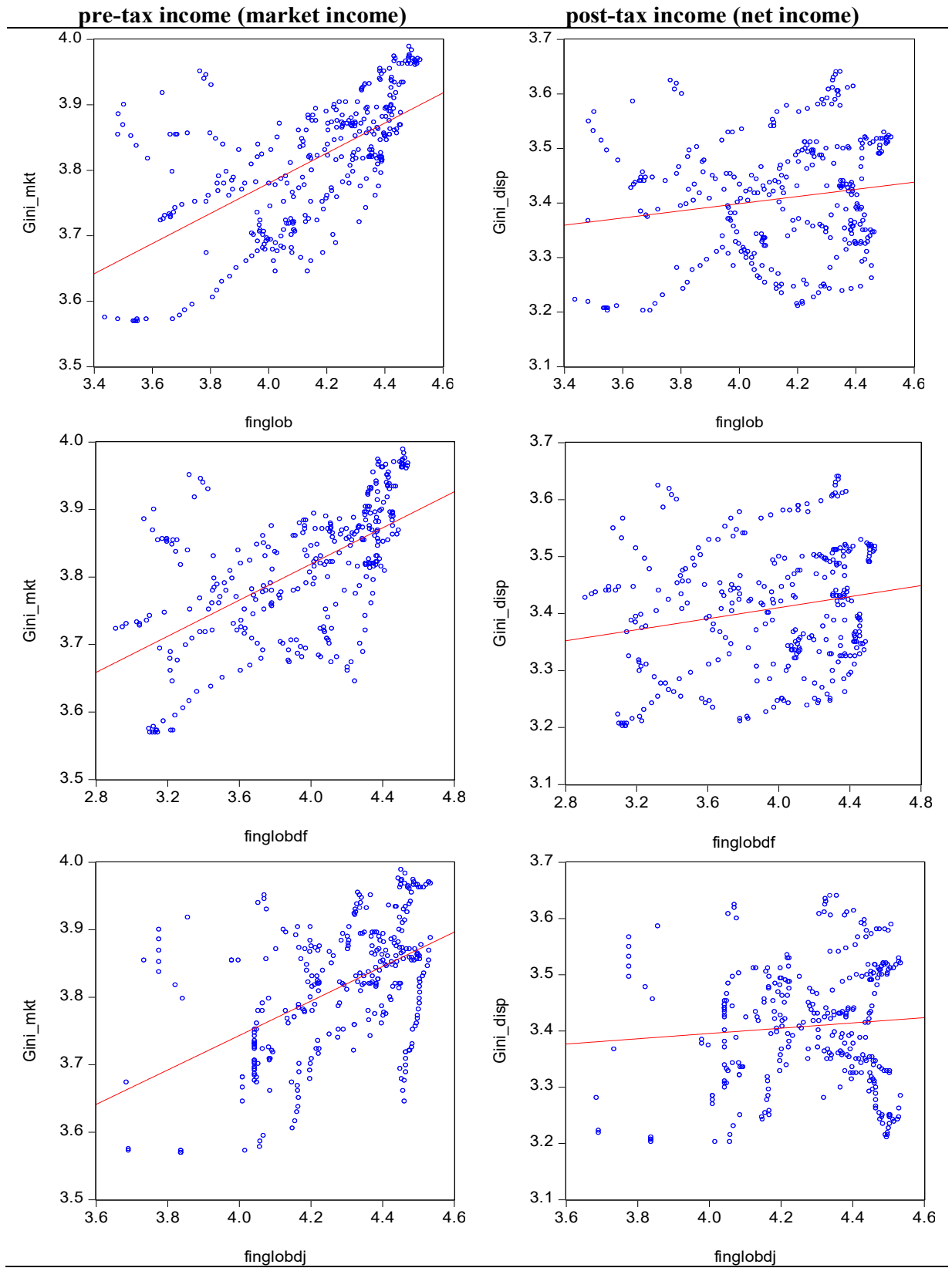

Source: Own graphs. Note: The natural logarithmic forms of all variables are used in the analysis. Gini_disp: Gini value in disposable income (post-tax). Gini_mkt: Gini value in market income (pre-tax). finglobdf: financial globalization (de facto). fnglobdj: financial globalization (de jure). finglob: financial globalization (overall). 
Appendix 2: The Role of Tax on the Effect of Income Inequality on Financial Globalization for G7 Countries (1970-2015)
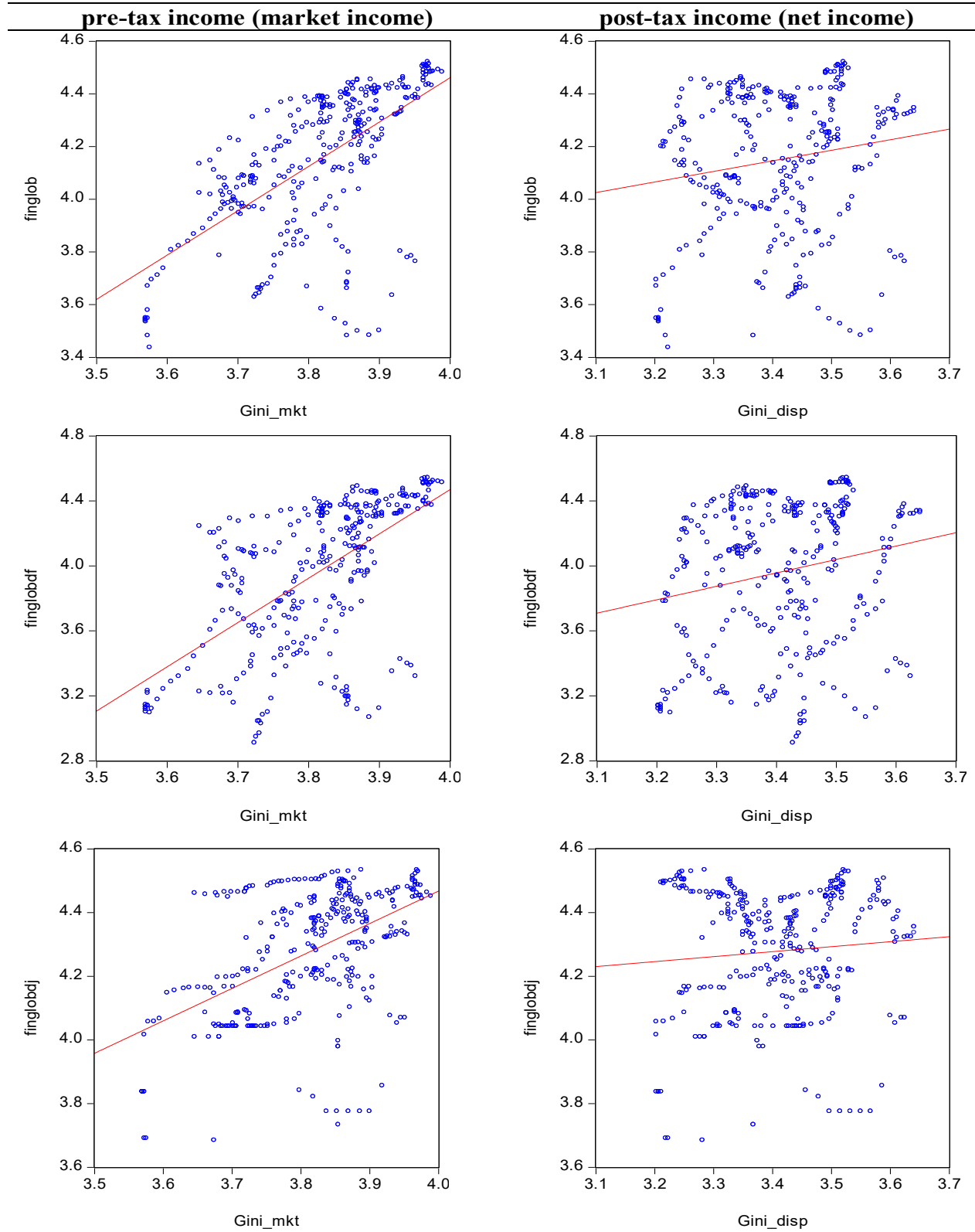

Source: Own graphs. Note: The natural logarithmic forms of all variables are used in the analysis. Gini_disp: Gini value in disposable income (post-tax). Gini_mkt: Gini value in market income (pre-tax). finglobdf: financial globalization (de facto). fnglobdj: financial globalization (de jure). finglob: financial globalization (overall). 